\title{
Analysis of Government Collaborative Action on Covid-19 Disaster Management in Lampung Province
}

\author{
Simon Sumanjoyo Hutagalung \\ Departement of Public Administration, Universitas Lampung (email: simon.sumanjoyo@fisip.unila.ac.id)
}

\author{
Eko Budi Sulistio
}

\begin{abstract}
Anticipation act in disaster management is important, including non-natural disasters such as the COVID-19 pandemic. This research aims to examine the government colaborative action in dealing with covid-19 non-natural disasters in Lampung Province. This research is an experiment study, using pretes-post design methods with group control. The population in this study was 84 people from stakeholders in regional disaster management, the group was divided into 2 groups: groups that intervened through model and groups that intervened with disaster relief without model. The sample of the study results is carried out with representative criteria and relevant criteria. In this study a large sample based on that criterion was 70 people who were divided into 2 groups. The instrument used is a questionnaire. Based on the results of the known paired $t$ test there is a difference between the pretest and postest values in each group namely the experiment group $(p=0,001)$ and the control $(p=0,001)$, based on the $t$ test based on the value of the $p=0.006$ result, which means there is a difference in disaster management knowledge in the significant stakeholder group between the post test group I and the control group.
\end{abstract}

\section{Keywords:}

disaster management; collaborative action; government collaboration; covid-19 pandemic

\section{Introduction}

Various experiences of natural disasters faced by humans have given learning to various parties to change the mindset and way of tackling them. In this development era is increasingly realized how important inter-relations between the parties in each process and stage of disaster management (Cavallo, 2014). Both the government and the public should both have readiness and ability to prevent, confront, evade, or cope with natural disasters that can strike without knowing the time of the event (Caymaz et al., 2013). If the government and the community in an area are more alert to face and able to cope with the disaster, the impact of the losses that the community will experience and that area is likely to be suppressed or 
minimized. Conversely, if the government's disaster management is poor and the community remains powerless then the losses from natural disasters can become greater or even more complicated to overcome (Hermansson, 2016).

In the midst of a paradigm shift in disaster management in a more encouraging direction, disaster risk reduction becomes commonplace from decentralized development processes. In Indonesia, attention to the importance of disaster management has at least been realized through the birth of Law No. 24 of 2007 on Disaster Management. Under the Law, local governments are required to form a task force of the Regional Disaster Management Agency, i.e. in each province up to the district/city level (Anantasari et al., 2017).

But the mere perness of the organizational structure is certainly not enough. That is why in the development of more up-to-date disaster management ways and practices simultaneously the demands for better governance of disaster management are also increasingly real (Pandey, 2019). Transparency, participation and accountability in the interrelations of the parties of both the government, the public and the business world will determine what the quality and success of a disaster management activity will look like. The experience of some areas in carrying out the rehabilitation-reconstruction of the homes of people affected by the aftermath of the earthquake is even considered to be one of good practice and should be used as a stub for learning for various parties (Ali et al., 2019). Disaster management developed by local governments in a transparent, participatory and accountable manner can be the key to optimizing the achievement of disaster management goals (Arbon, 2014).

Governance has a very important meaning and role in ensuring the achievement of the most basic objectives of a political entity, be it the country or the smaller political regions under it, including such as provinces and districts/cities in Indonesia. In the context of governance and development, good governance will benefit democracy and the welfare of the people (Cutter et al., 2013). By UNDP governance is defined as a process, rule, or result of interaction between legislative, executive, civil society, courts, and communities that are then referred to stakeholders in a particular region. In this case governance is defined as the rationing of power in the fields of economics, politics and administrative to manage a country at all levels (Ariyanto, 2018). On the one hand governance can be interpreted as formal and informal rules governing public areas, especially in the decision-making process. In addition, 
governance is also defined as the capacity of the government to design, formulate, and implement policies and impose penalties on offenders (Etinay et al., 2018). Governance as a process of public policymaking and its implementation through interaction between the state arena, civil society, and economic society (market) (Anderson et al., 2019). Meanwhile, governance is the process of aligning culture, political institutions and economic systems that grow and develop in society with the main goal of creating a better shared life (Enia, 2016). The various definitions of governance stated above demonstrate how important it is to pay attention to interrelasi between the parties in making decisions, planning, preparing, implementing to evaluate each process and phase of disaster management (Daly \& Feener, 2016). In particular from the point of view of inter-relationship social science studies the parties themselves can be studied as an embodiment of social reality as well as a phenomenon of social action.

With regard to the context of good governance in disaster management in the region there must be at least three principal governance principles in the inter-relations of the parties, namely: transparency, participation and accountability (Das \& Luthfi, 2017). First, transparation concerns the openness of public information as the main foundation of good governance in disaster management. Second, participation to ensure the involvement of all relevant parties, especially the community as the main benefit of the agenda and rehabilitation-reconstruction program. Third, accountability in the sense that all parties can and must account for decisions and actions or actions taken. Good governance practices at least apply these three principles and are then referred to by the Partnership as the basis for a more collaborative governance.

In previous research, a model was obtained that sought to summarize the involvement of stakeholders in disaster management. This model has a payload that emphasizes potential aspects for collaboration and collaboration with non-governmental and private groups in handling long-term disaster victims, bearing in mind that the government budget only covers the relocation and construction of houses and public infrastructure affected by disasters, while the needs of other supporters are not ready yet. The rehabilitation and reconstruction phase requires solid commitment. As has been stated if after the disaster it is possible ithere iis a concentrationiof NGOs in the relief and rescue phase. However, continuing efforts in the reconstruction and rehabilitation phase require long-term 
commitment. In this phase, NGOs can play an important role as a link between the community and the government, communicating the needs and priorities of the community to the government. Therefore, the most challenging part is the aspect of readiness to play a role, where the capabilities involved in post-disaster reconstruction can be transmitted to future generations to anticipate the next disaster (Shaw, 2003). The dynamics in the role of the government shows that if the government cannot become self-government, in the context of disasters more collaboration and tactical collaboration between stakeholders is needed, only the position of non-government groups can be further strengthened. Under these conditions, more governmental networks are generally needed more as a decentralized organization and joint network governance that can facilitate collaboration by optimizing trust and legitimacy and minimizing power imbalances (Hermansson, 2016). In addition, community involvement in disaster risk reduction and pre-disaster management can provide benefits in terms of trust, ownership and reduction of losses due to disasters due to dynamic processes that enable community groups to contribute, exchange ideas and inclusive decision-making activities (Pandey, 2019). The future model of disaster management needs to be multi stakeholder and involve more active roles of non-government groups and private organizations that have the capacity to manage disasters.

In the next section it is necessary to be disseminated in the form of testing the concept of models against the group that is the implementer of the model. This dissemination needs to be done to prepare for acceptance and minimize rejection by the group, in addition the results of such dissemination can also result in revision or strengthening of the model in order to strengthen the relevance and optimization of the model. Therefore, there are several objectives that are to be realized from this study, namely: (1). Is there any influence of complementary network models on the knowledge of disaster management stakeholders in the region?, (2). Are there any changes before the model was introduced with after the introduction of that model?. These two questions will then be discussed in the next section.

\section{Methods}

In experimental research there are principles that must be met namely the absence of replication, randomization, and control. If the research of the three principles is fulfilled but has not yet reached perfect (actually) then it is called quasi experimental. The type of research 
used is quasi-experimental because it has not yet reached perfect in the experiment group and control group (Wang et al., 2018).

This research was conducted with the research design of pretest-posttest control group design. With the same draft, the same questionnaire was tested to the same group of respondents twice. While the time between the first test (pretest) and the second (posttest), not too far, but also not too close. Intervals between 15-30 days are sufficiently qualified (Bärnighausen et al., 2017). If the interval is too short then it is likely that the respondent still remembers the questions in the first test. Whereas if the test time is too long, it is likely that in the respondent there has been a change in the variable to be measured. In this study the time span given between pretes and postes in both the experiment and control groups was the same for 25 days.

The population in this study was 84 people, consisting of stakeholders in disaster management, with the following details: 1) 22 people from district government apparatus; 2) 22 people form BNPB and Basarnas apparatus; 3). 20 people from NGO activists number, and 4). 20 people of academician. From the two groups are divided into 2 groups; group 1: intervention through model socialization, and group 2: without model socialization. Determination of research samples is done purposively sample, i.e. sampling method to get certain criteria as the criteria in question are criteria of relevance and criteria representativity.

In this study a large sample based on these criteria, obtained 70 person. With a sample of 70 person, the number of representative samples because it is more than a minimum sample then with random method is divided into 2 groups namely group 1: model socialization intervention as many as 35 person, Group 2: intervention control group is done without model socialization as many as 35 people.

\section{Result and Discussion}

\section{a. Disaster Management Collaborative Model}

Disaster response and recovery efforts encourage the growth of various humanitarian organizations. Long (1997) mentions an increase in the number of humanitarian aid operations, along with the number of natural disasters in the world. Disaster damage requires assistance not only from the government in disaster response and recovery efforts. The increasing number of disaster events in various countries encourages the growth of aid 
organizations. The corporate sector also played a role in relief efforts. Thomas and Fritz's (2006) research on relief efforts during the tsunami in Aceh shows the role of various companies. Situations and conditions resulting from disasters require active preparation and greater resources to achieve the goals carried out (Daly, 1998).

The government, according to Helsloot and Ruitenberg (2004), may not be able to respond to all aspects of disaster response and recovery efforts alone, thus encouraging the involvement of various other resources. Paul (1998), shows the involvement of organizations in disaster relief, including Non-Governmental Organizations (NGOs) or Non-Governmental Organizations (NGOs), professional and business organizations, volunteers, soldiers and other organizations, as well as involvement of other communities outside the disaster area. Disaster response and recovery efforts are also supported by other countries in the world. The international community plays a role in assisting victims in efforts to recover the consequences of disasters, both short and long term.

These organizations are agents in disaster response and recovery efforts. Butcher and Ashton (2004) mention the term agency as an independent organization that works in accordance with its objectives, so that the term agents in disaster response and recovery efforts includes various organizations. The term agency denotes an organization that aims to provide services to society. Organization by Camphoux (2003) is defined as a system that involves the collaboration of two or more people to achieve goals. Agents in disaster response and recovery efforts, are classified differently by Kodoatie and Syarief, and by Dynes. Kodoatie and Sjarief (2006) classify parties involved in disaster response and recovery efforts into five groups, namely: regulators, planners, users, support organizations and service providers. provider). Dynes (1970), as quoted by Scanlon, states that there are four types of organizations that respond to emergency situations, namely regular, expanding, extending and emergency groups. Organizations with regular duties have regular duties such as police and security. Cross organization expanding broader tasks such as medical officers. Even if not direct, the extension organization has a role in disasters, for example, contracting companies. Emergency groups are groups that are formed specifically for example committees, agencies, and special teams.

Meanwhile, Shaw (2003) argues that the coordination of NGOs and volunteer organizations in a post-disaster scenario can be concluded that activities will be successful if 
they are rooted in people and communities. Community involvement is important because community activities are deeply rooted in the society and culture of a region. They can show the real needs and priorities of the problems faced, so that they can provide responses and corrections to plans to be implemented. The existence of community participation in the form of groups, community groups (grassroots) is an important factor in village development (Martin, 2004). Twigg, (1999) also states that the existence of community activities encourages people to respond to emergencies quickly, efficiently, fairly, and resources can be used economically. In developing and developing countries, according to Raphael (1986), during an emergency, community groups play a very important role in the process of disaster response and reconstruction. Shaw and Goda (2004) describe relationships in social interactions, including government, aid organizations, and communities. The community interacts uniquely with the environment and society. Disasters not only affect individuals and businesses, but also communities. When a community experiences a disaster, they will try to act (Flint and Luloff, 2005). Community resources are naturally deeply related to the environment and geography in which they are located.

\section{b. Colaborative Action of Covid-19 Pandemic in Lampung}

On the End of June 2020, hard work amidst the Pandemic in Lampung is appreciated. Lampung has been named the second best province in Indonesia which has successfully suppressed and controlled the spread of the Covid-19 virus. Not only that, innovations carried out in three sectors have received awards. New Productive and Safe Covid-19 Normal Order Area Innovations. The three sectors are 1st place in the restaurant sector, 2nd place in the modern market / mall sector and 3rd place in the traditional market sector.

The success of Lampung cannot be separated from various social movements in society, including the role of women in Lampung Province who take part. Under the command of the Governor's wife who is also the Chairperson of the Lampung Province TP PKK, Riana Sari Arinal. They don't want to be left behind. Take part in helping alleviate Covid-19 in the region. Social ideas are born. Forming the SIGER movement or Time to Join the Movement for the People. This movement targets people who have difficulty earning a living. As a consequence of the appeal to stay at home. In order to minimize the spread of the virus. Social movement in simple ways. The packages containing vegetables, eggs, instant noodles, sardines, oil, rice 
were placed in front of the fence of his house. A message was written. For those who need it, they can take something as needed. Apart from that, Riana also initiated Barokah Friday. Distribution of groceries and medical devices for people in various areas in Lampung Province. The hope is to motivate the whole community to share. Health workers who are at the forefront of handling the Corona virus are not ruled out. They need the availability of medical equipment. Starting from PPE, Face Shield, Portable Washbasin, given to health workers in hospitals and health centers. Do not forget to help with basic needs. Riana was not alone in preparing. He involved a lot of people.

Full support is also provided from the private sector. Various companies are working with the Lampung Provincial Government to distribute aid to people in need. Support from the company was distributed with the Covid-19 Handling Task Force. Support that never stops flowing. A lot of work has to be done. Apart from health and social safety nets, it is no less important to save the people's economy. Especially the Micro, Small and Medium Enterprises (UMKM) sector which has been a mainstay. Movement of the community economy. Decisions made. Providing stimulus to the Cooperative and MSME sector which was affected by the Covid-19 pandemic. In line with the steps of the Lampung Provincial Government, the Central Government has also moved to help the MSME sector. From the records of the Lampung Province Cooperative and UMKM Service, there are 1,683 MSMEs and 80 cooperatives affected by Covid-19. The stimulus for MSMEs is taken from the budget for handling the Covid-19 pandemic of IDR 246 billion. These funds are accumulated from central government budget assistance of Rp. 111 billion plus APBD and Special Allocation Funds (DAK) of Rp. 135 billion. The budget for handling the economic impact itself is prepared at Rp. 26.9 billion. The biggest is for handling the health sector. The value is IDR 181 billion. Big funds are also prepared. For a social safety net. For those who are poor and have lost their jobs due to the Corona pandemic. The budget is IDR 9.8 billion. For the procurement of 98,000 food packages for people affected by the Covid-19 pandemic in 15 districts / cities of Lampung Province.

\section{c. Data Experiment Test Analysis}

In this section analyzed data on assessments resulting from assessments of pre tests and post tests conducted to stakeholder groups that became respondents. In the beginning, 
please be aware of the meaning of the pre test and post test in order to know the change in the value of both types of tests. The results can be seen from the table below:

Table 1.

Test Results t Pre Test Scores and Post Test Experiment Groups

\begin{tabular}{lllll}
\hline & & Deviation & & \\
Value & Mean & & p value & N \\
& & Standart & & \\
\hline Pre Test & 78,05 & 10,09 & & \\
& & & 0,001 & 35 \\
Post test & 89,25 & 7,29 & & \\
\hline
\end{tabular}

In the table, there is known to be an increase in the average (mean) of knowledge scores before and after being given a socialization model. The increase can be seen from the average pre-test score of 78.05 increased to 89.25 . In the average post test score, the difference in knowledge score of the highest ecperimen group was 32, and the lowest 2 while the average difference between pre test and post test was 11.20

To find out if there is a difference between the pre test and post test values in this experiment group, a t-section test is performed. In the paired $t$ test, the data is said to be a difference between the previous value and the next value if the $p$ value is less than 0.05 . After testing, it was obtained that the $p$ value was 0.001 . This indicates that the $p$ value is less than 0.05 , so it can be concluded that there is a meaningful difference between the pre test and post test values in the experiment group.

Table 2.

Test Results t Pre Test Scores and Post Test Control Group

\begin{tabular}{lllll}
\hline & & Deviation & $\mathbf{p}$ & \\
Value & Mean & & & $\mathbf{N}$ \\
& & Standar & value & \\
\hline Pre Test & 78,80 & 7,89 & & \\
& & & 0,001 & 35 \\
Post test & 84,40 & 7,00 & & \\
\hline
\end{tabular}


In the table it is known that there is an increase in the average (mean) of knowledge scores before and after being given disaster management socialization without offending the substance of the model. The increase can be seen from the average pre-test score of 78.80 increased to 84.40 on the average post test score. The difference in knowledge scores of the Control group was 26 and the lowest 4 while the average difference between pre test and post test was 9.54. Based on the results of the $t$ test paired between the pre test and post test values in the control group value $\mathrm{p}=0.001(<0.05)$, it can be concluded there is a difference between the pre test and post test values in the control group.

Table 3.

Post Test Results and Control Group Post Test Scores

\begin{tabular}{lcccc}
\hline & \multicolumn{4}{c}{ Deviation } \\
Value & Mean & Standart & & \\
& & & & \\
\hline $\begin{array}{l}\text { Post test } \\
\text { (Experiment) }\end{array}$ & 89,25 & 7,27 & 0,006 & 35 \\
Post test & & & & \\
(Control) & 84,40 & 7,00 & & \\
& & & & \\
\hline
\end{tabular}

In the table, there is a mean difference in post-test knowledge scores between the experiment group and the control group. These differences can be seen from the average post test score of 89.25 with a standard deviation of 7.27 and the control group of 84.40 with a standard deviation of 7.00 .

Based on the results of the $t$ test analysis did not match between post test group I and control group obtained $p=0.006<0.05$. Based on the analysis can be found that there is a significant difference in knowledge between the post test group I (there is a socialization model) and the control group. This means that the model which diseminate its substance is effective in improving the knowledge of disaster management stakeholders in the region.

\section{Conclussion}

Disaster management is important for handling disaster events in order to reduce or minimize casualties. The government cannot afford to handle disasters alone. The 
involvement of various parties in the relief effort is an important factor. The success of disaster management cannot be separated from the roles of various parties, including the government, humanitarian organizations and the community (grassroots). Various cooperation will provide enormous benefits. The interaction of civil society which includes government, humanitarian organizations and communities is a force for the sustainability of disaster management more quickly and effectively, in short and long terms covering local areas where disasters occur. This collaborative model has been tested to be positively accepted by the results of data analysis.

Based on data analysis, it can be concluded that: (1). There are differences in the knowledge of disaster management stakeholders in known areas from the increase in pre test and post test scores, (2). There is a model influence on the increasing knowledge of disaster stakeholders in disaster management in the region.

\section{Acknowledge}

We would thanks to the Ministry of Education for funding this research through the Higher Education Research Scheme scheme, especially PTUPT scheme. In addition to that we also thank the research institutes of Lampung University for administrative and institutional support.

\section{References}

Ali, M. S. S., Arsyad, M., Kamaluddin, A., Busthanul, N., \& Dirpan, A. (2019). Community based disaster management: Indonesian experience. IOP Conference Series: Earth and Environmental Science, 235, 012012. https://doi.org/10.1088/1755-1315/235/1/012012

Anantasari, E., Daly, M., Glassey, P., Grace, E., Coomer, M., \& Woods, R. (2017). Disaster risk reduction (DRR) Capacity and Capability of Local Government in Indonesia. In R. Djalante, M. Garschagen, F. Thomalla, \& R. Shaw (Eds.), Disaster Risk Reduction in Indonesia: Progress, Challenges, and Issues (pp. 127-155). Springer International Publishing. https://doi.org/10.1007/978-3-319-54466-3_5

Anderson, M. B., Woodrow, P. J., \& Woodrow, P. J. (2019). Rising From The Ashes: Development Strategies In Times Of Disaster. Routledge. https://doi.org/10.4324/9780429304859 
Arbon, P. (2014). Developing a model and tool to measure community disaster resilience. Australian Journal of Emergency Management, The, 29(4), 12.

Ariyanto, D. (2018). Koordinasi Kelembagaan Dalam Meningkatkan Efektivitas Badan Penanggulangan Bencana Daerah. Management Review, 2(1), 161-171. https://doi.org/10.25157/jmr.v2i1.1118

Bärnighausen, T., Røttingen, J.-A., Rockers, P., Shemilt, I., \& Tugwell, P. (2017). Quasiexperimental study designs series-paper 1: Introduction: two historical lineages. Journal of Clinical Epidemiology, 89, 4-11. https://doi.org/10.1016/j.jclinepi.2017.02.020

Cavallo, A. (2014). Integrating disaster preparedness and resilience: A complex approach using system of systems. Australian Journal of Emergency Management, The, 29(3), 46.

Caymaz, E., Akyon, F. V., \& Erenel, F. (2013). A Model Proposal for Efficient Disaster Management: The Turkish Sample. Procedia - Social and Behavioral Sciences, 99, 609-618. https://doi.org/10.1016/j.sbspro.2013.10.531

Cutter, S. L., Ahearn, J. A., Amadei, B., Crawford, P., Eide, E. A., Galloway, G. E., Goodchild, M. F., Kunreuther, H. C., Li-Vollmer, M., Schoch-Spana, M., Scrimshaw, S. C., Stanley, E. M., Whitney, G., \& Zoback, M. L. (2013). Disaster Resilience: A National Imperative. Environment: Science and Policy for Sustainable Development, 55(2), 25-29. https://doi.org/10.1080/00139157.2013.768076

Daly, P., \& Feener, R. M. (2016). Rebuilding Asia Following Natural Disasters: Approaches to Reconstruction in the Asia-Pacific Region. Cambridge University Press.

Das, A., \& Luthfi, A. (2017). Disaster Risk Reduction in Post-Decentralisation Indonesia: Institutional Arrangements and Changes. In R. Djalante, M. Garschagen, F. Thomalla, \& R. Shaw (Eds.), Disaster Risk Reduction in Indonesia: Progress, Challenges, and Issues (pp. 85-125). Springer International Publishing. https://doi.org/10.1007/978-3-319-54466-3_4

Enia, J. (2016). Rules versus discretion: Comparing disaster declaration institutions in the Philippines and Indonesia. International Journal of Disaster Risk Reduction, 16, 158-166. https://doi.org/10.1016/j.ijdrr.2016.02.010

Etinay, N., Egbu, C., \& Murray, V. (2018). Building Urban Resilience for Disaster Risk Management and Disaster Risk Reduction. Procedia Engineering, 212, 575-582. https://doi.org/10.1016/j.proeng.2018.01.074 
Hermansson, H. M. L. (2016). Disaster Management Collaboration in Turkey: Assessing Progress and Challenges of Hybrid Network Governance. Public Administration, 94(2), 333-349. https://doi.org/10.1111/padm.12203

Pandey, C. L. (2019). Making communities disaster resilient: Challenges and prospects for community engagement in Nepal. Disaster Prevention and Management: An International Journal, 28(1), 106-118. https://doi.org/10.1108/DPM-05-2018-0156

Shaw, R. (2003). Role of Non---Government Organizations in Earthquake Disaster Management: An Asian Perspective. Regional Development Dialogue, 24(1), 117-129.

Wang, C. (Alex), Zhang, X. (Michael), \& Hann, I.-H. (2018). Socially Nudged: A QuasiExperimental Study of Friends' Social Influence in Online Product Ratings. Information Systems Research, 29(3), 641-655. https://doi.org/10.1287/isre.2017.0741 